\title{
ドラム式電着ダイヤモンドワイヤ製造技術の開発
}

\author{
張 宇*1，谷 泰弘 ${ }^{* 2}$, 桐野 宙治*3，川波多 裕司 ${ }^{* 4}$
}

\section{Development of drum-type manufacturing method for electroplated diamond wire tools}

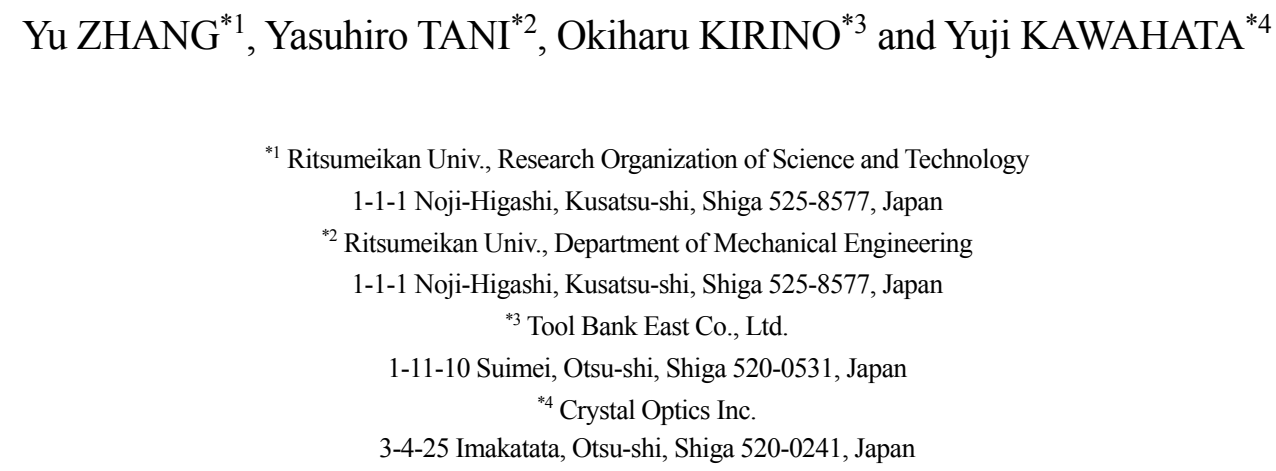

Received 19 April 2016

\begin{abstract}
Diamond wire saws are widely used in slicing various kinds of hard and brittle materials, such as silicon, sapphire, etc. Electroplated diamond wire tools are used for high-efficiency slicing process, because of high abrasion resistance. However, low production efficiency of diamond wire tools causes high cost in the production process, because the electroplating rate is low. To solve the problems, a drum-type manufacturing method for electroplated diamond wire tools was developed in this study. Multiple diamond wire tools could be manufactured simultaneously at high speed in one machine. The mechanism of drum type electroplating unit was introduced, firstly. Then the electroplating characteristics, such as maximum current density, Ni deposition rate and uniformity of electroplated wires, were evaluated. Composite electroplating experiments using diamond abrasive were carried out and the effect of electroplating factors on the amount of electrodeposited diamond grains was discussed, too. It was found that turbulence flow of electroplating solution could improve amount of deposited diamond grains. Long diamond wire tools were manufactured and used to slice Si ingot, it was confirmed that the developed wire tools have high slicing performance equal to the commercially available diamond wire tool.
\end{abstract}

Key words : Diamond wire tool, Wire sawing, Electroplating, Current density, Deposition rate, Slice

\section{1. 緒言}

エコブームや電力消費節約等の社会情勢が世界中に広がり, エネルギー政策における太陽電池や LED の需要性 が近年ますます高まっている. シリコン太陽電池に使われるシリコンウェー八や LED 用のサファイア基板は, マ ルチワイヤソーでインゴットをスライシング加工することにより製造される. スライシング加工においては，ピ アノ線を高速走行させながら加工液に GC 砥粒を䀣濁させたスラリーをかける研磨切断法とダイヤモンド砥粒を ワイヤに固着した工具を走行させて水溶性研削液のみをかける研削切断法がある (Webster and Tricard, 2004). 研 削切断方式は研磨切断方式に比べて 2〜3 倍程度の切断能力を有するため, 現在シリコン， サファイア， SiC など の硬脆材料の切断に研削切断方式の普及が進んでいる．固定砥粒ワイヤ工具には，レジンボンドまたは電着によ りダイヤモンド砥粒を固着したものがある. 電着ダイヤモンドワイヤ工具は，レジンボンドワイヤ工具より耐熱

No.16-00180 [DOI:10.1299/transisme.16-00180], J-STAGE Advance Publication date : 7 October, 2016

${ }^{* 1}$ 正員, 立命館大学総合科学技術研究機構（厂525-8577 滋賀県草津市野路東 1-1-1）

*2 正員, 立命館大学理工学部機械工学科

*3 正員，(株）ツールバンク（广520-0531 滋賀県大津市水明 1-11-10)

*4（株）クリスタル光学（广520-0241 滋賀県大津市今堅田 3-4-25)

E-mail of corresponding author: zhangyu@fc.ritsumei.ac.jp 
性，耐摩耗性に優れ，その加工技術に関して研究成果が多数報告されている（Clark et al.,2003, Chen et al.,2014). 市販の電着ダイヤモンドワイヤ工具に関しては, 直径 $\phi 100 \mu \mathrm{m}$ のピアノ線に平均粒径 $10 \mu \mathrm{m}$ 程度のダイヤモンド 砥粒を付着したシリコンスライシング用のものと, 直径 $\phi 160 \mu \mathrm{m}$ のピアノ線に平均粒径 30-40 $\mu \mathrm{m}$ 程度のダイヤモ ンド砥粒を付着したサファイア等高硬度材料のスライシング用のものの 2 種類が主に使用されている. さらに材 料ロスを低減するために電着ダイヤモンドワイヤ工具の細線化が進められている. 近年, 電着ダイヤモンドワイ ヤ工具の製造方法の改善等でその製造コストが低下してきているが，産業界においては電着ダイヤモンドワイヤ 工具の価格のさらなる低減を求めている。 このように重要性が上昇しているにもかかわらず, 電着ダイヤモンド ワイヤ工具の製造方法に関してはその報告が少ないのが現状である. 電着ダイヤモンドワイヤ工具の製造は, 電 着ダイヤモンドホイール等の製造に用いられている沈降共析法（榎本他，1989）ではなく, 分散めっき法が一般 的である．新しい電着ダイヤモンドワイヤ工具の製造方法に関しては，ブラシめっき法を用いた製造方式（千葉 他，2003），液流式電着めっき法を用いた製造方式（諏訪部他，2010），回転ドラム式装置による製造方式（諏訪 部他，2012）等が報告されている. しかし，いずれの方式においてもワイヤ工具のマルチ製造ができず製造コス トの低減に限界を生じている，電着ダイヤモンドワイヤ工具の製造コストは，その製造速度に直結しめっき皮膜 の成長速度に依存寸るため, 同時に数本のワイヤ工具が製造できる技術または高いめっき電流密度が得られる高 速めつき技術を活かしたワイヤ工具の高速製造技術が望まれている.

本研究では, 電着ダイヤモンドワイヤ工具のマルチ製造化かつめっき電流密度の向上による高速製造化を実現 するために，リング状の筒の中に多数本のワイヤを設置し，コアロータに取り付けられたフィンによりワイヤ近 傍のめっき液を激しく攪拌する電着ダイヤモンドワイヤ工具の製造方式を考案した．また，めっきの限界電流密 度やワイヤ円周のめっき皮膜の肉厚が均一になるためのワイヤおよび陽極の配置等について検討した. さらに, ワイヤの周方向に均一に砥粒を共析させるために，めつき液の流れを制御しワイヤの周囲にめっき液が均一に流 れるようにワイヤの前方に障害物を設置した. このドラム式装置を用いて試作した電着ダイヤモンドワイヤ工具 は，市販のワイヤ工具と同等な切断能力を有することが確認できたので報告する.

\section{2. ドラム式ダイヤモンドワイヤエ具製造方式の提案}

\section{$2 \cdot 1 \quad$ ドラム式ダイヤモンドワイヤエ具製造方式の概念および簡易めっき槽による検証}

現在電着ダイヤモンドワイヤ工具の製造においては, めっき液にダイヤモンド砥粒を懸濁させた電気ニッケル 分散めっき法が生産現場でよく利用されている．めっき皮膜の成長を高速化するためには，めっき電流密度を高 くすることが必須である，高いめっき電流密度を実現するために陰極付近の拡散層（金属イオン欠乏層）を常に 薄くしなければならない(川崎, 1969). その手段として陰極近傍に陽イオンを供給することができるようなジェ ット流めっき法やブラシめっき法が報告されている，著者らはブラシめっき技術を活用し，ロールブラシの回転

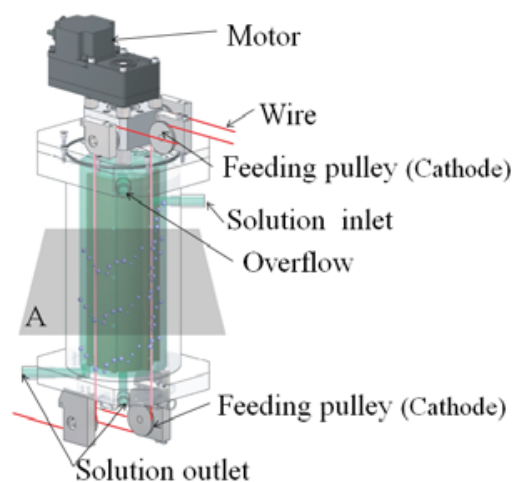

(a) Overall view

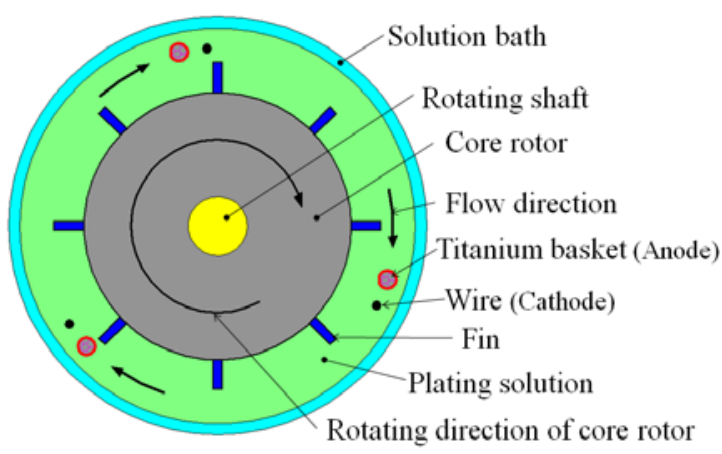

(b) Cross-section view of plane $\mathrm{A}$

Fig.1 Schematic of drum type plating unit. Several fins are fixed upon a core rotor. The anodes and the wires are set in the interspace between the metallic pipe and the fins. To improve the current density of plating, the plating solution is agitated strongly by the rotational fins. The drum type plating unit can plate multiple wires simultaneously and manufacture the diamond wire tools with high efficiency. 
により陽イオンが減少する陰極近傍のめっき液を覮拌し, 拡散層を薄くする効果を確認している(谷, 桐野, 2013). これは 2 本ブラシまたはフィンを付けた羽根車の間にワイヤを通す構造であり, ダイヤモンドワイヤ工具の高速 製造を実現した. 2 本の羽根車の中央部にワイヤを設置するブラシ方式では, 同時に多数本の電着ダイヤモンド ワイヤ工具を製造するためには多数の羽根車が必要となり，製造装置の設置面積が大きくなる，消費電力が大き くなるといった問題点があった.

本研究では，ブラシめっき式電着ダイヤモンドワイヤ工具の製造技術を改良し，コンパクトでありながら高い めっき電流密度が得られるドラム式電着ダイヤモンドワイヤ工具製造方式を提案する. 図 1(a)は 3 本のワイヤを 同時にめっきするドラム式めっき槽の外観を示す.ワイヤがほぼ空気が巻込みのないめっき槽内を走行しながら， ワイヤにめっきする構造である. めっき槽の上下部の給電プーリー (陰極) がワイヤに接触し給電する. めっき 液はタンクからポンプにより吸込み供給口よりめっき槽内に注入され，排出口からタンクに戻り循環させる. 図 1(b)はドラム式めっき槽の断面を示す. 羽根車（コアロータ）とめっき槽外壁の間にリング状の流路を形成し， 流路にワイヤやニッケルペレットを入れたチタンバスケット（陽極）を設置する.リング状の流路には複数本の ワイヤが簡単に設置できるため, 同時に多数本の電着ダイヤモンドワイヤ工具の作製が可能となる. 数枚のフィ ンが取り付けられた羽根車をめっき槽上部のモー夕により回転し，槽内のめっき液を攪拌する．めっき液が強力 に攪找されることによりワイヤ付近の拡散層が薄くなり高いめっき電流密度が得られると考えられる.

ドラム式電着ダイヤモンドワイヤ工具の連続製造装置を作る前に，図 2 に示される簡易的なドラム式めっき槽 を作製し，ドラム式装置のめっき特性を検証した．めっき槽の外壁として汎用のビーカを用い，ビーカの下部に

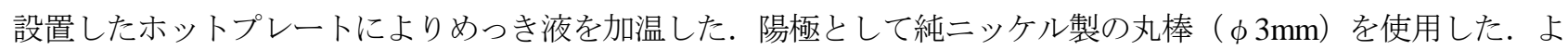
り均一にワイヤに給電できるようにめつき槽の内側に補助電極としてチタン製の金属パイプも設置した. フィン の先端と金属パイプの内側の距離はおよそ $10 \mathrm{~mm}$ であり, 陰極のワイヤ（ $\phi 0.25 \mathrm{~mm} ）$ と陽極のニッケル棒をフィ

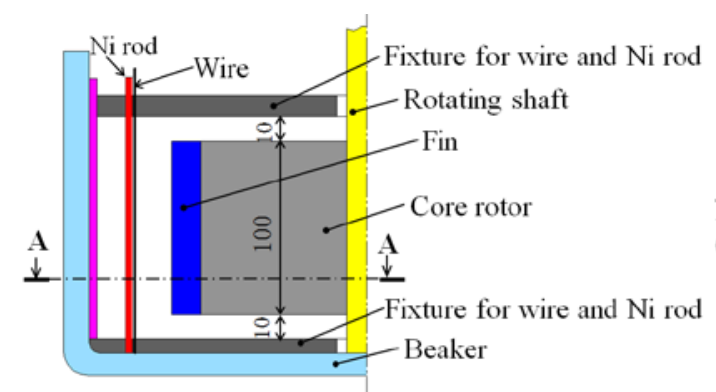

(a) Sectional side view

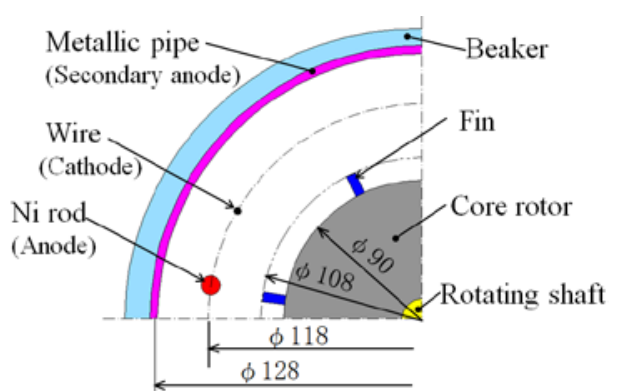

(b) Section view along line A-A

Fig.2 Schematic of simple drum type plating unit. The core rotor fixed up 8 fins is rotated by the rotating shaft. A wire (cathode) and a nickel rod (anode) are fixed on the up and down fixtures. The fixtures are set in a beaker. For improving the current distribution around the wire a metallic pipe is located on the inner wall of beaker as a secondary anode.

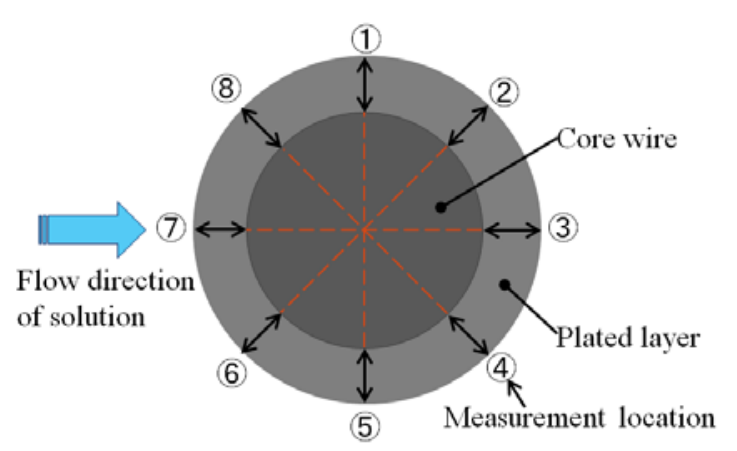

(a) Section of plated wire

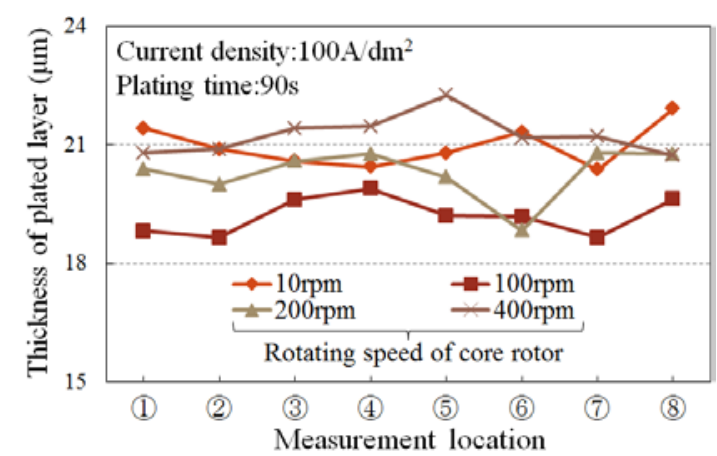

(b) Thickness of plated layer around wire

Fig.3 Variation of thickness of plated layer in circumferential direction of wire caused by the rotating core rotor. The growth rate of plated layer is independent of the rotating speed of core rotor. The variation of thickness of plated layer in circumferential direction of wire is small, too. 
ンの先端と金属パイプ内側の中間に設置した. モータのシャフトは上部で支持し, モータにより羽根車を回転し， めっき液を攪挥する. 金属パイプ上のめっき液の境界層厚さを理論的に計算すると $1 \mathrm{~mm}$ 以下であり (加藤, 1989), ワイヤは流れるめっき液の中央部付近（壁による影響がない領域）に設置した．なお，ドラム式簡易めっき槽を 用いた基礎実験では，ワイヤは走行させずニッケル丸棒と同じく上下の治具に固定した.

ブラシめっき式ダイヤモンドワイヤ工具製造装置においては，2 本の羽根車が逆方向に回転した場合めっき液 がワイヤの片側に当たるため砥粒の析出が偏るのに対し，2 本の羽根車が同方向に回転すればワイヤの全面がよ り均一にめっき液が当たりワイヤに析出した砥粒の分散性が向上寸ることが分かっている (桐野, 谷, 2011). 本 研究で開発したドラム式電着ダイヤモンドワイヤ工具の製造装置においてもめっき液が一方向に流れるため砥粒 の偏析現象が生じるが，第 3 章でその解決方法を詳細に述べる．なお，砥粒を入れない場合，ワイヤの円周方向 におけるめっき皮膜の成長速度に関しては, 図 3(a)に示されるようにワイヤの円周方向に 8 個所のめっき皮膜の 厚さを測定した結果 (図 3(b)), そのばらつきが少ないことが確認されている.したがって，ワイヤの円周に析出 した砥粒の分散性が悪くなる原因がめっき皮膜の成長速度によるものではないことがわかる.

\section{$2 \cdot 2$ ドラム式めっき槽のめっき特性}

めっき実験を行う前に芯線であるピアノ線の前処理として, 有機溶剂による脱脂洗浄を行った後, 10vol\%の塩 酸溶液よりピアノ線表面の油脂や防錆用の黄銅膜を完全に取り除いた. 表 1 はめっき実験の基本条件を示寸. 電 着応力が小さく, 高いめっき電流密度が得られるようにスルファミン酸ニッケル浴を使用した. ドラム式めっき 槽のめっき特性が調べやすいように, 実際の電着ダイヤモンドワイヤ工具のめっき層よりめっき皮膜を厚くした. まず，陽極のニッケル棒と陰極のワイヤとの電極間距離による限界電流密度（図 4(a)に示されるようなめっき焼 けが生じない最大のめっき電流密度）の変化を調べた．図 4(b)に示されるように金属パイプに通電せずニッケル 棒のみに通電した場合にはニッケル棒とワイヤの距離が長くなるにつれて限界電流密度が下がった，一方，金属 パイプにも通電した場合には，ニッケル棒とワイヤの距離による限界電流密度の変化がほとんど見られず高い電 流密度を維持できることが分かった。 これはニッケル棒とワイヤ間の電極間距離が大きくなるにつれ，めっき液 の電気抵抗が増えニッケル棒からワイヤへの電気供給が少なくなったためである．それに対して金属パイプにも

Table 1 Basic electroplating condition.

\begin{tabular}{l|lr}
\hline & $\mathrm{Ni}\left(\mathrm{NH}_{2} \mathrm{SO}_{3}\right)_{2} \cdot 6 \mathrm{H}_{2} \mathrm{O}$ & $600 \mathrm{~g} \mathrm{~L}$ \\
& $\mathrm{NiCl}_{2} \cdot 6 \mathrm{H}_{2} \mathrm{O}$ & $10 \mathrm{~g} \mathrm{~L}$ \\
& $30 \mathrm{~g} \mathrm{~L}$ \\
\hline & $\mathrm{H}_{3} \mathrm{BO}_{3}$ & \\
\hline Core wire & Piano wire, $\phi 0.25 \mathrm{~mm}$ & \\
\hline Temperature of plating solution & $60{ }^{\circ} \mathrm{C}$ & \\
Plating time & $120 \mathrm{~s}$ & \\
$\mathrm{pH}$ & 4 & \\
\hline
\end{tabular}
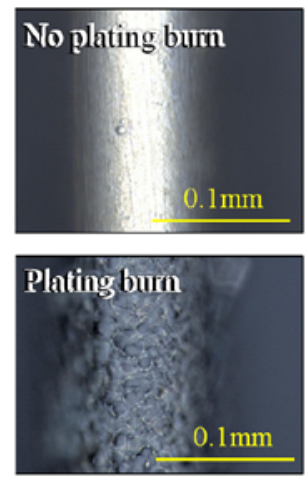

(a) Plated wire

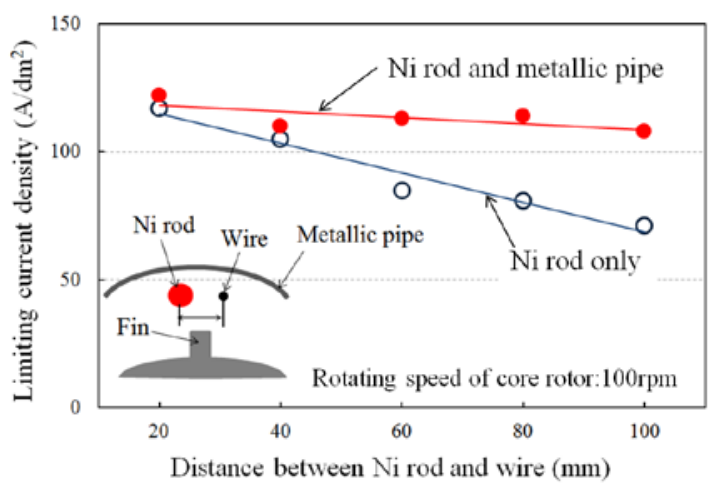

(b) Limiting current density

Fig.4 Effect of anode configuration on limiting current density. The addition of a metallic pipe can prevent plating burn and improve the limiting current density in the plating process. 
通電した場合はめっきに必要な電気量がワイヤに十分に供給できたと考えられる.

次に, 羽根車の回転速度がめっきの限界電流密度やめっき皮膜の成長速度に与える影響を調べた. 図 5(a) に示 されるように羽根車の回転速度を 100rpm から 200rpm に増加すると限界電流密度が約 2 倍に向上寸ることが分か った．めっき液が激しく攪拌されるとワイヤ付近の拡散層が薄くなりワイヤへの $\mathrm{Ni}^{2+}$ 供給が改善されたため限界 電流密度が向上したと考えられる．しかし，回転速度が 200rpm 以上になると限界電流密度が低下寸る傾向が現 れた。 これは，羽根車が高速に回転するとめっき液の攪拌が激しくなり，図 5(b)に示されるようにニッケル棒後 方のめっき液（赤枠の中）に空気が巻き込まれたためと考えられる. 巻き込まれた空気が $\mathrm{Ni}^{2+}$ の供給を妨げ，ワ イヤの焼けが発生した．また，めっき皮膜の成長速度は電流密度にほぼ比例することが確認できる.

図 1 に示されるように羽根車とめっき槽の外壁が形成されたリング状の流路に多数本のワイヤを同時に設置す ることにより，ドラム式めっき槽を用いてダイヤモンドワイヤのマルチ製造が可能である. 複数本のワイヤに同 時に電気を流した場合, ワイヤ間に電気的な干渉が生じ, めっき膜厚の均一性が劣ることが考えられる. そこで, めっき膜厚の均一性を調べるため，図 6(a)に示すようにめっき槽に 2 本のワイヤを同時に設置し，それぞれのワ イヤに析出しためっき皮膜の円周方向の厚さばらつきを調査した. 図 6(b)に示すように, 1 本ずつ通電した場合 にはめっき液が一方向に流れてもワイヤの円周方向の膜厚のばらつきはほとんどなかった．それは，ワイヤ附近 には， $\mathrm{Ni}^{2+}$ が十分に供給され，2本のワイヤ間に電気的な干渉がなかったためと考えられる. それに対して 2 本の ワイヤに同時に通電した場合, ワイヤ間距離によってめっき皮膜の厚さばらつきが大きくなることが分かった. 特にワイヤ同士が接近した場合（ワイヤ間距離： $2 \mathrm{~mm}$ ）では，めっき皮膜の厚さばらつきが最も大きくなった. 図 7 はめっき後のワイヤ断面の一例を示す. 1 本ずつ通電した場合にはワイヤの円周における膜厚はほぼ均一と

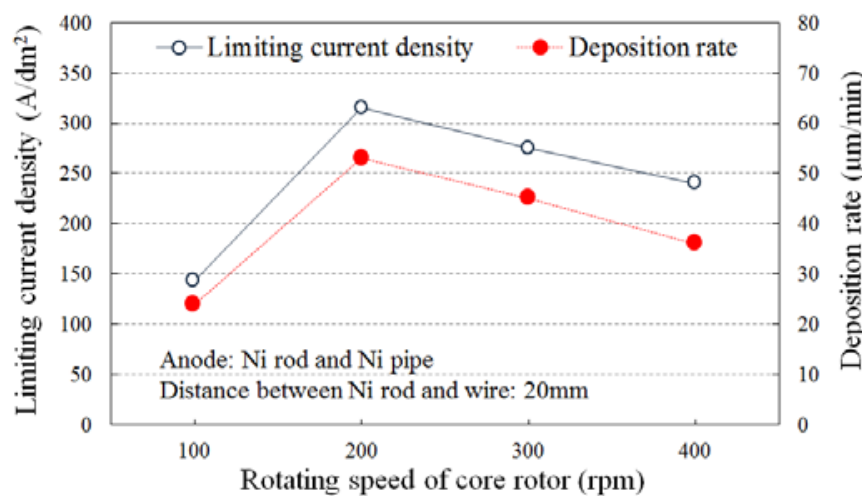

(a) Variation of limiting current density and deposition rate

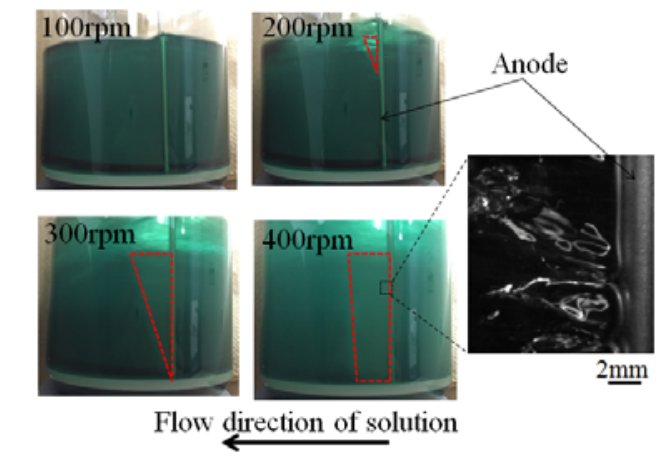

(b) Appearances of plating solution

Fig.5 Effect of rotating speed of core rotor on limiting current density, deposition rate and plating solution. The limiting current density can be improved by increasing the rotating speed of core rotor, except for the case of air is involved into the plating solution.

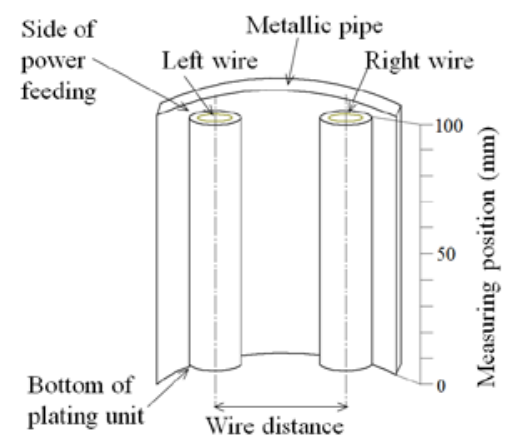

(a) Arrangement of wires

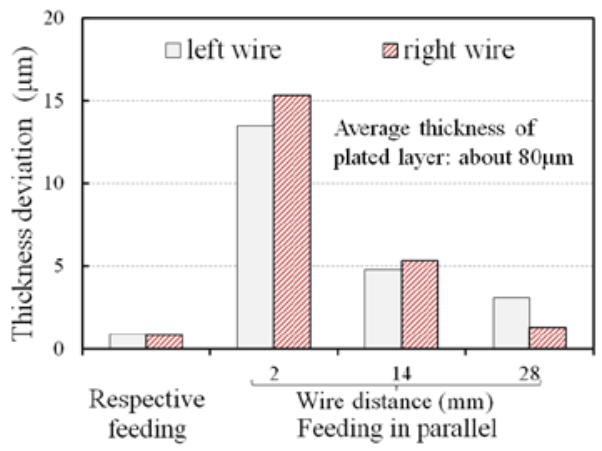

(b) Effect of wire distance on thickness deviation

Fig.6 Thickness distribution of plated layer around wires. In the case of feeding to left or right wire respectively, the standard deviation of the nickel layer thickness is much lower than that of feeding left and right wires in parallel. The thickness deviation is larger as the distance of left and right wires is nearer and nearer, especially. 
なったが, 2 本のワイヤに同時に通電するとワイヤの断面がカム形状を呈していることが確認される. 2 本のワイ ヤに同時に通電するとワイヤ間の電気的な取り合いが複雑となり, ワイヤに析出するめつき皮膜が円周方向で不 均一となったと推察した。ワイヤ間距離が小さくなるほどめっき膜厚の均一性はさらに悪化した. ワイヤ間距離 が $28 \mathrm{~mm}$ の場合には膜厚の最大と最少の差が $8.9 \mu \mathrm{m}$ であったのに対し， $2 \mathrm{~mm}$ の場合には $37.2 \mu \mathrm{m}$ とった. ワイ ヤ間距離が $2 \mathrm{~mm}$ の場合, 膜厚の最大と最少の差が平均膜厚の 5 割程度となっており, ダイヤモンドワイヤ工具 の性能に大きく影響を与えると予想される. ワイヤ間距離が $28 \mathrm{~mm}$ になると, ワイヤ間の電気的な取合いが軽減 し平均膜厚の 1 割以下に収まり, ダイヤモンドワイヤ工具の性能への影響がほとんどなくなったと考えられる. なお，同時に数本のワイヤ工具を製造するドラム式めっき槽を設計する際，給電プーリーの設置スペース等を考 慮すればワイヤ間距離を 50mm 以下にすることが事実上困難であるため, ワイヤ間距離によるめつき膜厚の影響 がほとんどないと考えられる.

\section{$2 \cdot 3$ ワイヤに析出する砥粒の分布}

ダイヤモンド砥粒をめつき液に分散した複合めつきの実験条件を表 2 に示す。上述のように攪拌フィンを取り 付けた外壁を羽根車と逆方向に回転させれば，ワイヤへの砥粒の析出は均一になると予想されたが，外壁を回転 させるには構造が複雑となり消費電力も増加するため, 羽根車のみを回転させて均一に砥粒を析出させることが できないか検討した。 図 8(a)に示すように，めつき液が一方向から流れるためめつき液とワイヤがぶつかる面に は砥粒が析出せずめっき液に流されることが分かった．それに対してめっき液の流れに対してワイヤの後方には めっき液の渦 (乱流) が生じ (東, 1999), 数多くの砥粒が付着した. したがって, ワイヤの周囲にめっき液の乱

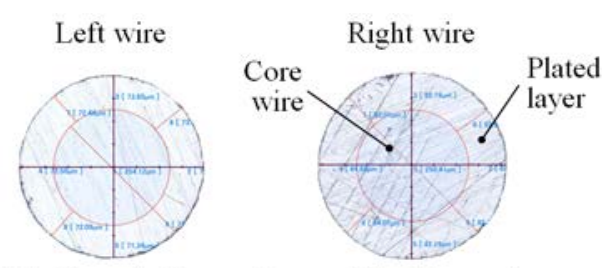

(a) Power feeding one by one, Wire distance: $2 \mathrm{~mm}$ (Variation of thickness: $2.7 \mu \mathrm{m}$ )

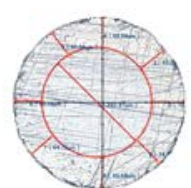

(c) Wire distance: $14 \mathrm{~mm}$

(Variation of thickness : $12.5 \mu \mathrm{m}$ )
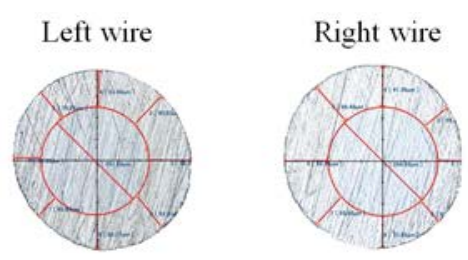

(b) Wire distance: $2 \mathrm{~mm}$

(Variation of thickness : $37.2 \mu \mathrm{m}$ )

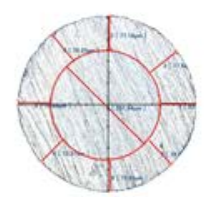

(d) Wire distance: $28 \mathrm{~mm}$

(Variation of thickness : $8.9 \mu \mathrm{m}$ )
Fig. 7 Cross section of two wires plated in parallel. The variation of plated layer in circumferential direction of wire is large in the case of plating near 2 wires.
Table 2 Composite plating condition.

\begin{tabular}{c|c}
\hline Wire & Piano wire, $\phi 0.12 \mathrm{~mm}$ \\
\hline Abrasive & $\begin{array}{c}55 \mathrm{wt} \% \text { Ni-coated } \\
\text { diamond abrasive, } \\
\text { Grain size: } 10 \sim 15 \mu \mathrm{m}\end{array}$ \\
\hline $\begin{array}{c}\text { Abrasive } \\
\text { concentration }\end{array}$ & $5 \mathrm{~g} / \mathrm{L}$ \\
\hline Drum rotating speed & $200 \mathrm{rpm}$ \\
\hline Current density & $160 \mathrm{~A} / \mathrm{dm}^{2}$ \\
\hline Plating time & $3 \mathrm{~s}$ \\
\hline
\end{tabular}

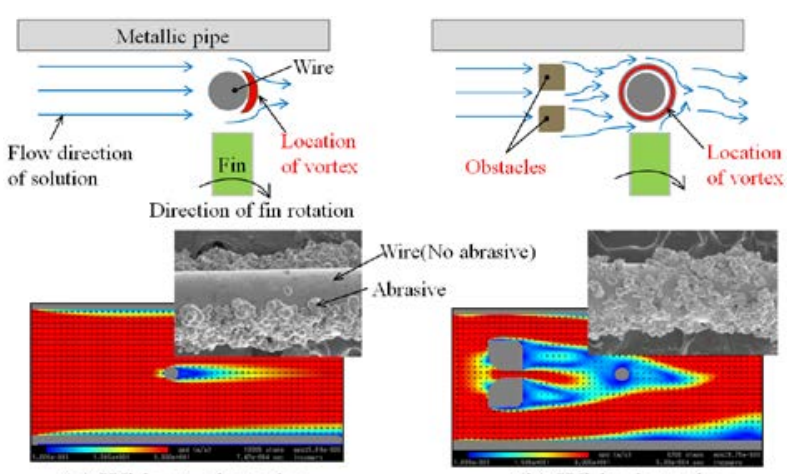

(a) Without obstacles

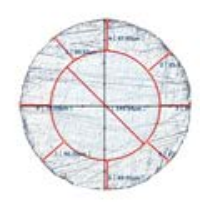

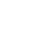

Fig. 8 Uniformity in abrasive distribution with obstacles. The obstacles
located in from of wire can cause vortex around the wire and improve the distribution of abrasives deposited on wire. 
流を生じさせることができれば，砥粒の付着を均一化にさせることができるではないかと考えた，そこで，ワイ ヤ周囲のめっき液の流れを制御するためにワイヤの前方にめっき液の流れに対する障害物を設置することにした. 2 次元流体解析ソフト（Flowsquare3.1b）により障害物の形状や位置の最適化を行った結果， ワイヤの前方に 2 本 の柱状障害物を設置することでワイヤ周囲に乱流を形成することができた（浅沼，1977）。めっき液の流れを制御 することにより, 図 8(b)に示されるようにワイヤの周囲に砥粒が均一に付着できることが確かめられた.

\section{3. ドラム式ダイヤモンドワイヤエ具の連続製造装置}

\section{$3 \cdot 1$ 連続製造装置の開発}

電着ダイヤモンドワイヤ工具の製造工程は, 芯線の活性化処理工程, 下地めっき工程, 複合めっき工程, 後め っき工程, 洗浄工程等で構成される. 電着ダイヤモンドワイヤ工具の素材とするピアノ線は防錆のために軟らか い黄銅めっきが施されているため，そのうえにニッケルめっきが成長するとダイヤモンドワイヤ工具の使用時に めっき皮膜が剥離されやすい，そのため，ニッケルめっき皮膜と芯線の密着強度を向上させるために，有機溶剤 による脱脂洗浄を行った後, アルカリ電解等で黄銅層を取り除くなどの前処理が行われる. そして, 露出したピ アノ線とめっき皮膜の密着性を向上するために塩酸よりワイヤ表面の活性化を行ってからウッド浴やワット浴に よりニッケルストライクめっき（下地めっき）を施した後, ダイヤモンド砥粒を固着させる複合めっきを行う. その後, 砥粒の保持力を向上させるために後めっき（砥粒の保持強度を高める埋め込みめっき）を施す．最後に 純水でワイヤを洗浄し，防錆材を塗布する.

前章では，簡易的なめっき槽を用いてドラム式めっき槽による電着ダイヤモンドワイヤ工具の製造が可能であ ることを確認した，本節では，電着ダイヤモンドワイヤ工具を連続的に製造する装置を提案する，電着ダイヤモ ンドワイヤ工具製造装置で最も重要となるめっき槽は, ワイヤ工具の製造速度や品質に大きく影響する. ドラム 式めっき槽を使用することにより高いめっき電流密度が得られるため, ワイヤ工具連続製造装置の寸べてのめっ き槽は図 9(a)に示されるドラム式めっき槽にした. ポンプによりめっき液タンクからめっき液を送り出し，めっ き槽上部の流入口からめっき槽内にめっき液を注入し, 下部の流出口よりめっき液タンクに戻す構造である. 簡 易めっき槽と同じく上部に設置したモータにより羽根車を回転し，めっき液を攪汼する．めっき槽上下部に設置 したステンレス鋼製のプーリーによりワイヤ（陰極）に給電する. 電気めっき用ニッケルペレットを充填したチ タンバスケットを可溶性陽極として使用した。 また, チタン製パイプをめっき槽の内壁に設置し, 不溶性の補助

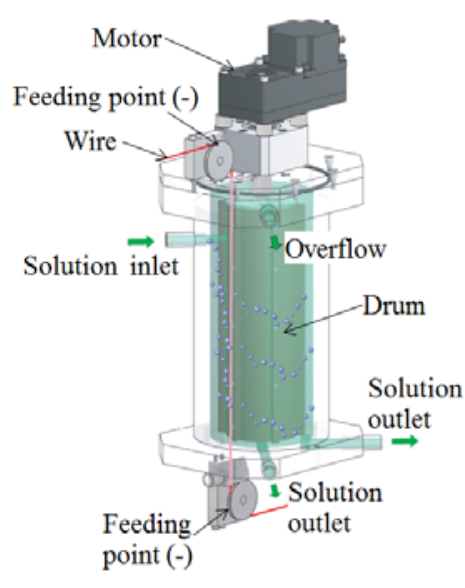

(a) Drum type plating unit

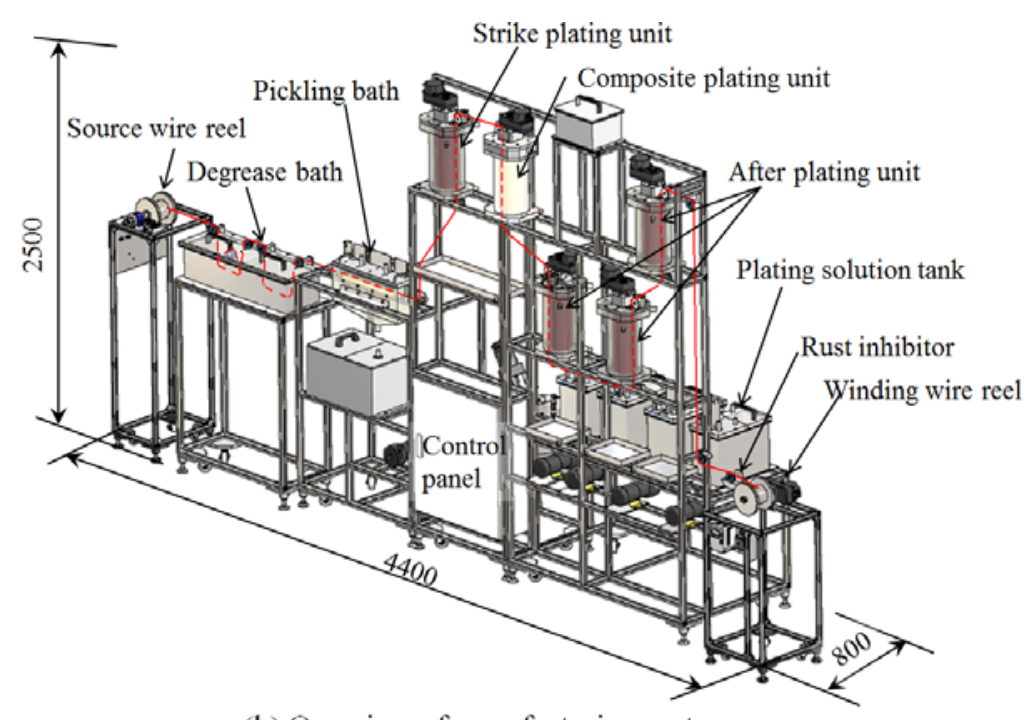

(b) Overview of manufacturing system

Fig. 9 Continuous manufacturing system of diamond wire tools. Power feeding points of wires are set the top and the bottom of plating unit. The manufacturing system consist of a pretreatment equipment, 1 strike plating unit, 1 complex plating unit, 3 after plating units and a post treatment equipment and equipment of winding wire. 
電極として使用した。チタンバスケットとチタンパイプの上部より電気供給を行った。 めっき槽の中央に外径が $\phi 90 \mathrm{~mm}$ のプラスチック製円柱に 6 個のフィンを取り付けた羽根車を設置した. フィンの先端からプラスチック 製円柱までの距離は $10 \mathrm{~mm}$ とした. 円筒容器の内径は $\phi 130 \mathrm{~mm}$ であるが，厚さ $1 \mathrm{~mm}$ のチンパイプを使用した ためフィンの先端とチタンパイプ内壁との距離は $9 \mathrm{~mm}$ である. ドラム式めっき槽の高さについては，めっきで きる有効高さが 350mm であるが，550mm まで延長できるように設計した。 ドラム式めつき槽ではめつき液がほ ぼ密閉されるため, 有害ガスの排出が少なく作業環境がよい. このドラム式めつき槽は, 内部容積が約 $2 \mathrm{~L}$ であ り，一般的なめつき槽に比べてめつき液の使用量が少ないという長所がある. ドラム式電着ダイヤモンドワイヤ 工具製造装置の全貌を図 9(b)に示す. ワイヤの巻出部, 脱脂, 酸洗・活性化, 前めっき（1 槽），複合めっき（1 槽), 後めつき (3 槽), 防錆剂塗布部, ワイヤの巻取部, めつき液の温度やドラムの回転制御などを行うコント ローラ部で構成される. 各めっき槽にはめつき液を蓄積するタンク（容量 : 10L）がついており, 個別にめっき 浴の管理を可能にした。 ウッド浴は，強酸浴であり陰極付近に大量の水素ガスを発生し，陰極付近において還元 䨌囲気で工具母材の表面酸化物を還元しながらめっきすることが可能で，母材とめっき皮膜との密着性が良くな る.そのため，ストライクめつき工程にはウッド浴を選択した．砥粒を析出させる工程の複合めつき浴と砥粒の 保持力を高める後めっき工程には，電着応力が小さく成膜速度が高いスルファミン酸ニッケル浴を選択した。 ま た, 高い成膜速度を維持するため塩基性炭酸ニッケルとアミド硫酸を用いて複合めつき浴と後めつき浴の $\mathrm{pH}$ を 4 程度になるように管理した。

\section{$3 \cdot 2$ めっき条件による電着特性の影響}

開発したドラム式ダイヤモンドワイヤ工具の連続製造装置を用いて簡易めつき槽と比較しながらめつき槽のめ つき特性を調べた。図 10(a)に示されるように羽根車回転速度の増加につれてめつきの限界電流密度が向上し, 簡 易めつき槽と同様の傾向になることが確かめられた。 なお，本めつき槽はほぼ空気の巻込みがないため，羽根車

\begin{tabular}{|c|c|c|c|c|}
\cline { 2 - 5 } \multicolumn{1}{c|}{} & \multicolumn{4}{c|}{ Rotating speed of core rotor (rpm) } \\
\hline $\begin{array}{c}\text { Current density } \\
\left(\mathrm{A} / \mathrm{dm}^{2}\right)\end{array}$ & 100 & 200 & 300 & 400 \\
\hline 170 & 0 & $\bigcirc$ & $\bigcirc$ & $\bigcirc$ \\
\hline 180 & 0 & $\bigcirc$ & $\bigcirc$ & $\bigcirc$ \\
\hline 190 & $\Delta$ & $\bigcirc$ & $\bigcirc$ & $\bigcirc$ \\
\hline 200 & $\mathrm{X}$ & $\Delta$ & $\triangle$ & $\bigcirc$ \\
\hline 210 & $\mathrm{X}$ & $\mathrm{X}$ & $\mathrm{X}$ & $\triangle$ \\
\hline 220 & $\mathrm{X}$ & $\mathrm{X}$ & $\mathrm{X}$ & $\mathrm{X}$ \\
\hline \multicolumn{4}{|c|}{ O:good $\Delta$ :partial plating burn } & X:plating burn \\
\hline
\end{tabular}

(a) Variation of limiting current density

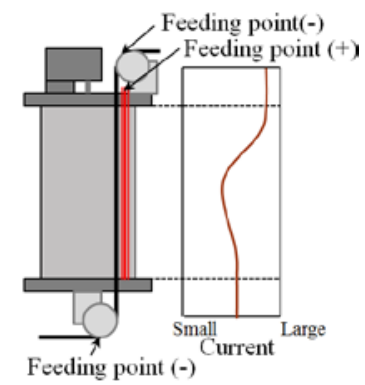

(b) Current distribution

Fig.10 Limiting current density depending on rotating speed of core rotor. It was confirmed that air are not involved into the plating solution and the limiting current density increases with the rotating speed of core rotor. The wire exposed to air is burned in high current density.

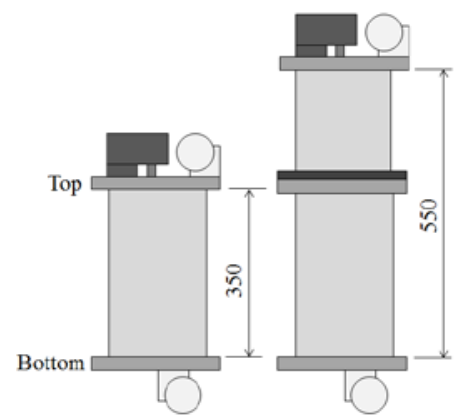

(a) Image view of plating unit

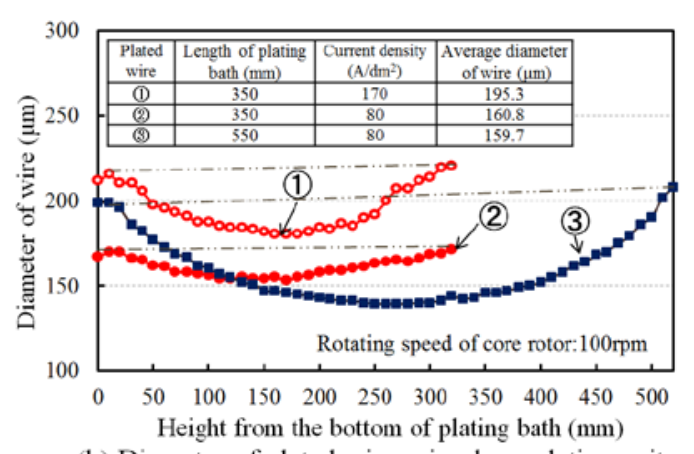

(b) Diameter of plated wire using long plating unit

Fig.11 Diameter of wire deposited at various height form the bottom of plating bath. The current density of central portion of plating unit is lower than that of top or bottom of plating unit, because the power feeding point is far. The short plating bath $(350 \mathrm{~mm})$ is more suitable for plating wire than the long one, because of a higher current density can be applied to wire. 
の回転速度の上昇による限界電流密度の低下がないことがわかった。しかし，連続製造装置のドラム式めっき槽 を用いた場合には，簡易めっき槽より限界電流密度が $1 / 2$ ほどまで低下した．簡易めっき槽に使用されたワイヤ は長さが $100 \mathrm{~mm}$ 程度でありワイヤに流れる電流が小さいため, ワイヤの電気抵抗による発熱量が少ない. それ に対して，連続製造装置のめっき槽ではワイヤの電極間距離が $350 \mathrm{~mm}$ となったため，簡易めっき槽と同じ電流 密度でめっきを行った場合ワイヤに流れる電流が 3.5 倍ほど大きくなり発熱量は $3.5^{2}$ に比例し多くなる. また, 給電部とめっき液の液面の間が空気中に暴露されたためワイヤに流れる電流（図 10(b)）が最も大きく, 発生した 熱が迅速に発散できずワイヤ焼けに至ったと考えられる．このようにはワイヤの電気抵抗により生じる熱が原因 で連続製造めっき槽の長さが制限されることが分かった．めっき液中にてワイヤへの給電ができれば，給電が分 散され発熱が少なくなりめっき槽をもっと長くすることが可能だと考えられる. 非接触給電方式を用いればこの 問題が解決できると考えられるが今後の課題とする.

長さが 350mm と 550mm の 2 種類のめっき槽（図 11(a)）を用い，ドラム式めっき槽の長さによるめっき膜厚の 分布を調べた. 析出しためっき皮膜の厚さ分布を測定するためにピアノ線を停止して 90 秒間のめっきを行った. めつきの電流密度が $100 \mathrm{~A} / \mathrm{dm}^{2}$ の場合には, 長さが $350 \mathrm{~mm}$ のめつき槽の場合 $1.32 \mathrm{~A}$ の電流が流れるが, 長さが $550 \mathrm{~mm}$ のめっき槽では 2.07A を流す必要がある. 前述したようにワイヤの電気抵抗による発熱等の原因で長さが $550 \mathrm{~mm}$ のめっき槽は限界電流密度が約 $90 \mathrm{~A} / \mathrm{dm}^{2}$ となった. 本実験では, めっきの安定性を考慮し, 2 種類のめつ き槽を用いて電流密度を同じく $80 \mathrm{~A} / \mathrm{dm}^{2}$ 一定にした実験と, 長さが $350 \mathrm{~mm}$ のめっき槽を用いて限界電流密度に 近い $170 \mathrm{~A} / \mathrm{dm}^{2}$ とした実験を行った. 図 11(b)にはめっき槽の高さ方向におけるめっき後のワイヤ直径が示され, めっき槽の上下部で膜厚が大きく中央部で小さくなっていることが分かる. 給電部付近の電流集中が大きくなり 析出したニッケル量が多くなるが，めっき槽の中央部では電流が小さいためめっき皮膜が薄くなったと推測され る.また，上部は下部よりめっき皮膜がやや厚くなっている．これは，陽極の給電部がめっき槽の上部だけ設置 されており，上部の電気集中が下部より大きいためである. 長さが $550 \mathrm{~mm}$ のめっき槽を使った場合には，めっ き槽の上下部（給電点に近い）のめっき皮膜が厚いが, めっき槽の中央部のめっき皮膜が上部の 2/3 ほどの厚さ しかなくめっき膜厚のばらつきが大きい，それに対して，長さが $350 \mathrm{~mm}$ の場合には，550mm のめっき槽と同様 な膜厚分布となるが，めっき膜厚がより均一であることが分かった．実際にワイヤ工具の製造工程では，ワイヤ が一定の速度でめっき槽を通過するため, めっき槽の高さ方向によるめっき膜厚の不均一という問題がワイヤ工 具の品質に影響を与えることはない. したがって，めっき槽を長くすることは，めっき電流密度を低下させるた
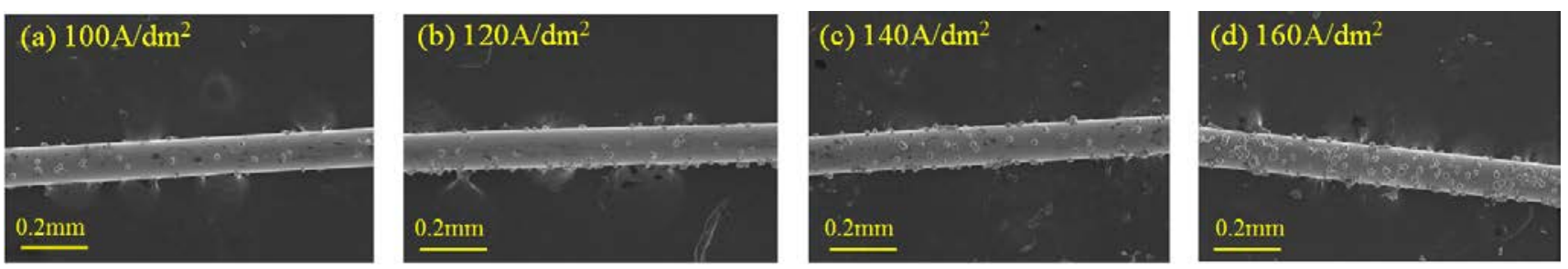

Fig.12 Effect of current density on deposited diamond abrasives. The diamond abrasives are distributed uniformly on wire tools. The abrasives increase in number as the current density is raised.
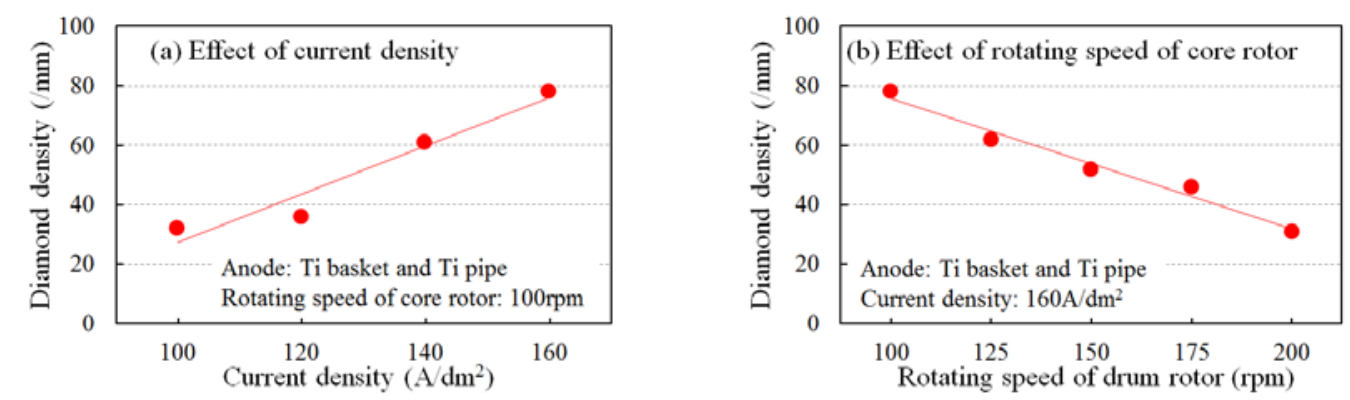

Fig.13 Effects of current density or rotating speed of core rotor on diamond density of wire tools. The density of dimond abrasives deposited on wire increases as current density and decreases as the rotating speed of core rotor. 
め, Ni の析出量が少なくワイヤ工具の高速製造に向かないことが分かった. めっき槽の数を増やせばめっき電流 密度が低下せず，ワイヤ工具の製造速度が向上できる.

簡易めっき槽を用いて砥粒の付着特性について検討した結果を利用し，連続製造装置の複合めっき槽に通過す るワイヤ附近に乱流を形成するようにワイヤの前方に 2 本の障害物を設置した．なお，本実験に使用しためっき 槽高さは $350 \mathrm{~mm}$ である. 図 12 にはめっき電流密度を変化させた場合の砥粒付着状態を示す. いずれの電流密度 においてもワイヤに付着した砥粒の分散性がよいことが確認できる. めっきの電流密度を変化した際のワイヤに 析出した砥粒の密度を図 13(a)に示寸. 析出した砥粒の量は電流密度に比例することが分かった. 電流密度が大き くなるにつれ，めっき皮膜の成長速度が高くなり，より短い時間に砥粒を固着することができたためと考えられ る. また, 羽根車の回転速度を変化した際のワイヤに析出した砥粒の密度を図 13(b)に示す. 羽根車の回転速度が 増えめっき液の流れが速くなると, 完全に固着していない砥粒が激しく流動するめっき液やめっき液中の砥粒よ り衝突されて流されてしまうため砥粒の付着量が減少したと考えられる. したがって, 羽根車の回転を速く寸る ことにより，めっき電流密度を向上させることができるが，ワイヤに析出した砥粒の量は低下してしまう．羽根 車の回転速度とめっき電流密度に関しては最適な複合めっき条件があることがわかった．なお，後めっき工程に 関しては砥粒の析出がないため, 羽根車の回転が速いほど高いめっき電流密度が得られるため好ましい.

\section{4. 作製した電着ダイヤモンドワイヤエ具の切断特性}

ドラム式電着ダイヤモンドワイヤ工具の連続装置を用いて $5 \mathrm{~m} / \mathrm{min}$ の製造速度で長さ $500 \mathrm{~m}$ のダイヤモンドワイ ヤ工具を試作した. シングルワイヤソー（WSD-K2，侏タカトリ社製）を用いて表 3 に示される切断実験条件で 多結晶シリコンインゴットのスライシングを行い, 電着ダイヤモンドワイヤ工具の切断特性を評価した. ワーク ローラに $0.3 \mathrm{~mm}$ のワイヤピッチでダイヤモンドワイヤ工具を 3 巻し, 2 枚のシリコンウェー八を切り出した. 研 削液に関しては水溶性研削液（MC-80C，トラスコ中山(株社製）を水で 30 倍に希釈したものを用いた.

図 14(a)は試作したダイヤモンドワイヤ工具により切断されたシリコンウェー八の写真を示寸. 多結晶シリコン インゴットからウェーハの割れを生じることなく切り出すことができた. 図 14(b)には切り出したウェー八の表面

Table 3 Schematic diagram and conditions of slicing test.

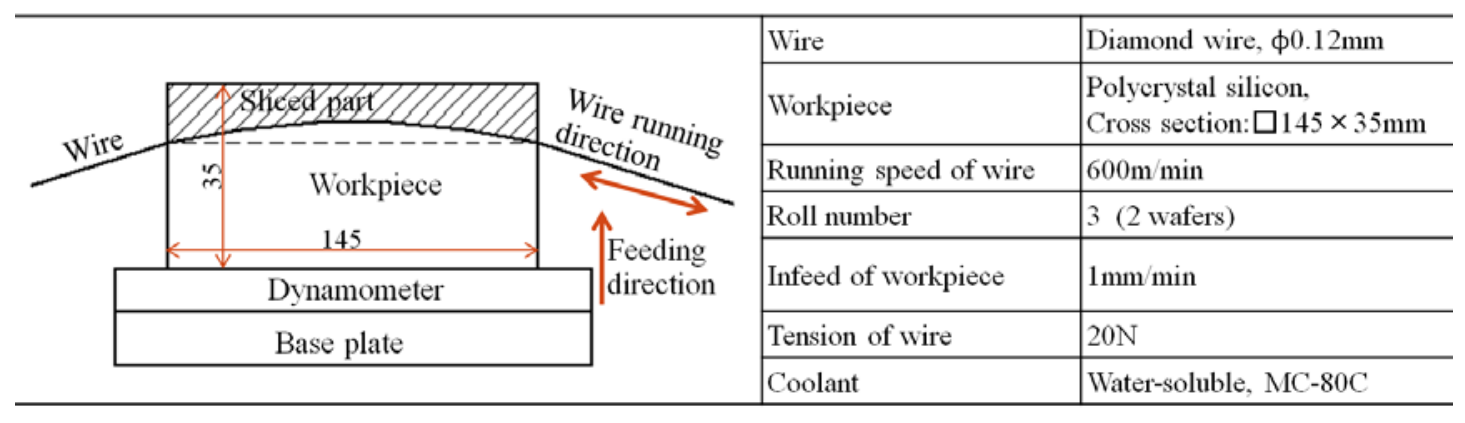

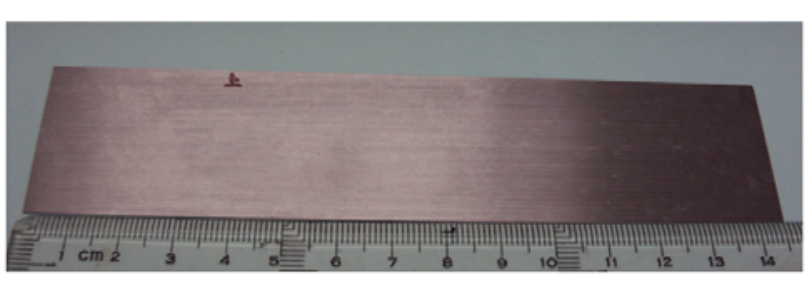

(a) Wafer sliced by wire tool of medium diamond density

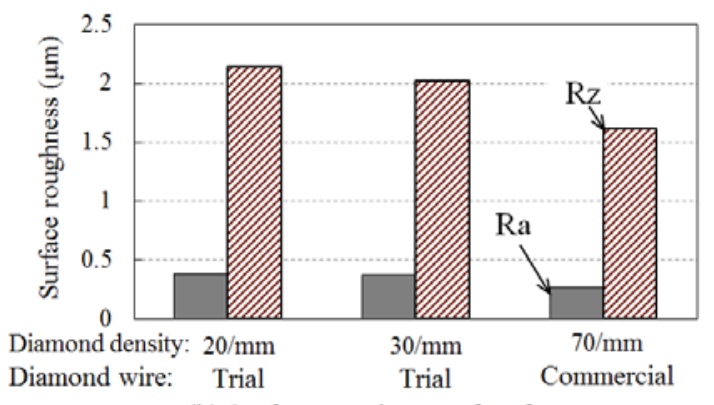

(b) Surface roughness of wafer

Fig.14 Photo and surface roughness of sliced silicon wafer. Polycrystal silicon can be sliced by the trial diamond wire tools. The surface roughness of sliced wafer is good by high density of diamond abrasive. 
粗さを示す. 試作したワイヤ工具を用いて切断されたシリコンウェー八の表面粗さは，市販のワイヤ工具により 切断したウェー八と同程度であることがわかる. また，固着した砥粒の密度が高いワイヤ工具を使用した場合， ウェー八の表面粗さがよくなることが確認される。これは，ワイヤ工具の砥粒密度が高いほど砥粒の平均切込み 深さが小さくなりウェー八の表面粗さが向上するためである. 使用したダイヤモンドワイヤ工具の切断前後の写 真を図 15 に示寸. 砥粒の先端に覆われたニッケル皮膜はなくなっているが, 砥粒の脱落等のワイヤ工具の性能に 大きく影響するダメージがないことが確認される．したがって，ドラム式電着ダイヤモンドワイヤ工具連続製造 装置を用いて高速にワイヤ工具を製造することが可能であることと，製造されたダイヤモンドワイヤ工具が高い 砥粒保持力を有することが確認できた.

\section{5. 結言}

本研究では, めっきの電流密度を向上することにより電着ダイヤモンドワイヤ工具の製造速度を高めることと 電着ダイヤモンドワイヤ工具製造のマルチ化を目的とし，ドラム式電着ダイヤモンドワイヤ工具製造法を提案し た．まず，簡易ドラム式めっき槽を用いてワイヤへのめっき特性を調査した．また，ドラム式電着ダイヤモンド ワイヤ工具製造装置を開発し，限界電流密度，砥粒の付着状態等について検討した，電着ダイヤモンドワイヤ工 具を試作し，多結晶シリコンの切断実験を行った，得られた結果は，以下の通りである.

(1) ドラム式電着ダイヤモンド工具の製造装置のめっき槽においては, めっき液が激しく攪拌され, $100 \mathrm{~A} / \mathrm{dm}^{2}$ 以上のめっき電流密度が実現でき, 高速に電着ダイヤモンドワイヤ工具の製造が可能であることが明らか になった.

(2) ドラム式めっき槽を用いて同時に数本のワイヤへのめっきができることが確認された. 数十 $\mathrm{mm}$ 程度の間 隔にワイヤを設置すればワイヤ間に電気的な取り合いがなく, ワイヤの円周に均一なめっき皮膜が得られ る.

(3) ワイヤの前方に障害物を設置することにより, ワイヤの周囲に乱流が形成されワイヤに析出した砥粒の分 散性を向上できることが分かった。

（4）めっき電流密度が高いほど羽根車の回転速度が低いほど，砥粒の析出量が多くなることが分かった．羽根 車の回転数を高くすることにより高いめっき電流密度が得られるが, 複合めっき工程には羽根車の回転速 度とめっき電流密度を総合的に考慮する必要がある.

(5) ドラム式電着ダイヤモンドワイヤ工具の連続製造装置を用いて試作したワイヤ工具は, 市販品と同等の切 断能力を有することが確かめられた。

\section{謝 辞}

最後に，本研究を行うに当たって実験に協力された立命館大学の元学生・楊聖みょう氏，Mohd Aizat 氏に心よ り感謝します．また，台湾の江信有限公司（FACT）よりダイヤモンド砥粒をご提供いただきました．ここに深く 感謝の意を表します.

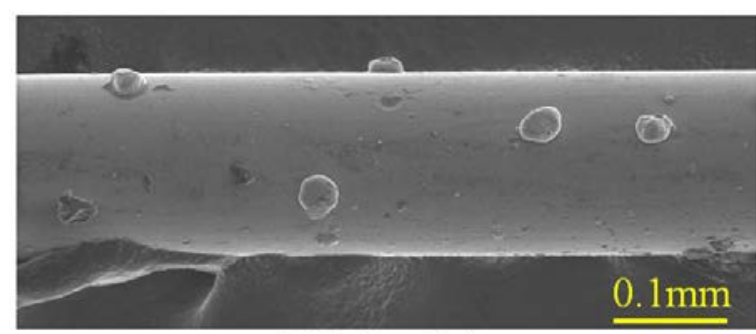

(a) Before slicing

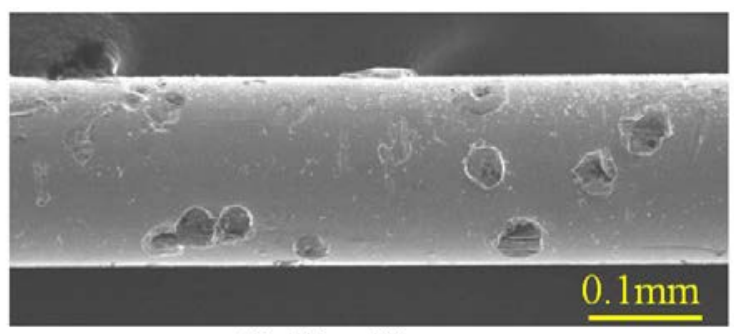

(b) After slicing

Fig.15 Photos of trial diamond wire tool having a diamond density of about 30/mm in before and after slicing test. The drop of diamond abrasives from the wire tool was not observed. It was confirmed that the diamond abrasives are fixed strongly on the wire by the drum-type manufacturing system. 


\section{文献}

浅沼強，流体の可視化ハンドブック，朝倉書店 (1977), pp.277-279.

東昭, 流体力学, 朝倉書店 (1999), pp.81-83.

Chen, W., Liu X., Li, M., Yin, C. and Zhou, L., On the nature and removal of saw marks on diamond wire sawn multicrystalline silicon wafers, Materials Science in Semiconductor Processing, Vol.27 (2014), pp. 220-227.

千葉康雅, 谷泰弘, 榎本俊之, 電着ダイヤモンドワイヤ工具の高速製造法の開発, 日本機械学会論文集 C 編, Vol.69, No.680 (2003), pp.303-309.

Clark, W.I., Shih, A.J., Hardin,C.W., Lemaster, R.L. and McSpadden, S.B., Fixed abrasive diamond wire machining — part I: process monitoring and wire tension force, International Journal of Machine Tools and Manufacture, Vol.43, No.5 (2003), pp. 523-532.

榎本英彦, 古川直治, 松村宗順, 複合めっき, 日刊工業新聞社(1989), p.4.

加藤宏, ポイントを学ぶ 流体の力学, 丸善株式会社 (1989), pp.63-66.

川崎元雄，高速めっきについて，金属表面技術，Vol.20, No.12 (1969), pp.621-627.

桐野宙治，谷泰弘，ブラシめっき法を適用した高速電着ダイヤモンドワイヤ製造方法の開発，2011 年度砥粒加工 学会学術講演会講演論文集 (2011), pp.261-262.

諏訪部仁, 秋充, 石川憲一, 回転ドラム式メッキ装置によるダイヤモンドワイヤ工具の高速作製法の開発に関する 研究, 砥粒加工学会誌, Vol.56, No.10 (2012), pp.703-708.

諏訪部仁, 大口敦史, 中村義弘, 石川憲一, 液流式電着メッキ法を用いたダイヤモンドワイヤ工具の高速作製法の 開発とその加工特性に関する研究，砥粒加工学会誌，Vol. 54, No. 5 (2010), pp. 298-303.

谷泰弘，桐野宙治，電着ダイヤモンドワイヤの高速製造技術の開発，砥粒加工学会誌，Vol.57， No.8 (2013), pp.498-501.

Webster, J. and Tricard, M., Innovations in abrasive products for precision grinding, CIRP Annals - Manufacturing Technology, Vol.53, No.2 (2004), pp.597-617.

\section{References}

Asanuma, T., Handbook of fluid visualization, Asakura Shoten (1977), pp.277-279 (in Japanese).

Azuma, A., Fluid mechanics, Asakura Shoten (1999), pp.81-83 (in Japanese).

Chen, W., Liu X., Li, M., Yin, C. and Zhou, L., On the nature and removal of saw marks on diamond wire sawn multicrystalline silicon wafers, Materials Science in Semiconductor Processing, Vol.27 (2014), pp. 220-227.

Chiba, Y., Tani, Y. and Enomoto, T., Development of a high-speed manufacturing method of an electroplated diamond wire tool, Transactions of the Japan Society of Mechanical Engineers, Series C, Vol.69, No.680 (2003), pp.303-309 (in Japanese).

Clark, W.I., Shih, A.J., Hardin,C.W., Lemaster, R.L. and McSpadden, S.B., Fixed abrasive diamond wire machining—part I: process monitoring and wire tension force, International Journal of Machine Tools and Manufacture, Vol.43, No.5 (2003), pp. 523-532.

Enomoto, H., Furukawa, N. and Matsumura, S., Composite plating, Nikkan Kogyo Shimbun (1989), p.4 (in Japanese).

Kato, H., Learning point Mechanics of fluid, Maruzen co., Ltd. (1989), pp.63-66 (in Japanese).

Kawasaki, M., High speed plating, Kinzoku Hyomen Gijutsu, Vol.20, No.12 (1969), pp.621-627 (in Japanese).

Kirino, O. and Tani, Y., Development of a high-speed manufacturing method of electroplated diamond wire utilizing brush plating, Proceedings of ABTEC2011 (2011), pp.261-262 (in Japanese).

Suwabe, H., Aki, M. and Ishikawa, K., High-speed processing of diamond wire tool by turn drum plating apparatus, Journal of the Japan Society of Grinding Engineers, Vol.56, No.10 (2012), pp. 703-708 (in Japanese).

Suwabe, H., Oguchi, A., Nakamaura, Y. and Ishikawa, K., Development of a high-speed manufacturing diamond wire tool by flow plating and slicing characteristics, Journal of the Japan Society of Grinding Engineers, Vol.54, No.5 (2010), pp.298-303 (in Japanese).

Tani, Y. and Kirino, O., Development of high-speed manufacturing technology for electroplated diamond wires, Journal of the Japan Society of Grinding Engineers, Vol.57, No.8 (2013), pp.498-501 (in Japanese).

Webster, J. and Tricard, M., Innovations in abrasive products for precision grinding, CIRP Annals - Manufacturing Technology, Vol.53, No.2 (2004), pp.597-617. 